\title{
TAX-PRICE ELASTICITY OF CHARITABLE DONATIONS - EVIDENCE FROM THE GERMAN TAXPAYER PANEL
}

\author{
Maja Adena
}

\section{Introduction}

The tax system in many countries is designed to encourage private donations to charities. In some countries, including Germany, donations can be deducted from gross income and therefore reduce individual tax liability. However, this imposes a cost on governments in the form of foregone tax revenue. For example, in 2001 in Germany, taxpayers declared a total of $€ 3.7$ billion of donations, of which $€ 2.9$ billion was recognized as deductible, thus reducing the tax revenue by approximately $€ 0.9$ billion. ${ }^{1}$ Thus, policy makers have a vital interest in assessing the effectiveness of allowing deductions to increase donations. The tax-price elasticity of donations is crucial for making this assessment and for evaluating potential policy changes. However, its value is unknown and has to be estimated. While there are numerous studies estimating taxprice elasticity of giving for the United States, the evidence for other countries is rather sparse. ${ }^{2}$ However, one should not believe that the estimates for the United States are also valid for other countries. Specifically, Germany differs much from the United States when it comes to the role of the government and the tradition of charitable giving. Total public social expenditures in Germany in 2001 amounted to $27.4 \%$ of GDP. By contrast, they were $14.7 \%$ of GDP in the United States. ${ }^{3}$ National giving levels are $1.67 \%$ of GDP in the United States, and they are $0.22 \%$ of GDP in Germany. Moreover, there are also strong regional differences in Germany. While in the former East Germany, the giving levels are $0.12 \%$ of GDP, they are $0.26 \%$ of GDP in West Germany. ${ }^{4}$

The United States and Germany also differ in the charitable goals that are primarily supported. While in 2010, 35\% of U.S. donations went to support religious goals, $14 \%$ to educational goals, and $9 \%$ to support human services, ${ }^{5}$ the numbers for Germany were: $33 \%$ for emergency relief, $24 \%$ for child welfare, and $24 \%$ for foreign aid. ${ }^{6}$ Around two-thirds of private donations in Germany are paid in the form of membership fees for nonprofit associations and organizations. ${ }^{7}$ Membership fees are usually of a fixed, prespecified value and are often automatically debited from members' bank accounts. ${ }^{8}$ This could imply that German donors will be less responsive to small changes in price or that adjustments in contributions may occur after a time lag.

Given that donations have not been studied extensively in Germany, ${ }^{9}$ this chapter contributes to closing this gap in a number of ways and fully exploits the advantages of the longitudinal 
character of the data set. First, it accounts for omitted variable bias coming from individual unobserved characteristics (like education, wealth or degree of altruism) that are potentially correlated with income and marginal tax and are known to be important determinants of donations. Second, it accounts for the endogeneity of the tax-price and after-tax income variables by appropriate instruments. Third, it helps to overcome the identification problems while using the tax reform implemented gradually in 2004 and 2005. Moreover, it allows to identify permanent and transitory tax-price and income elasticity and to understand whether donors adjust their charitable giving gradually in response to tax changes and whether they respond in advance to known future changes. Finally, this study allows tax-price and income elasticity to vary by income class.

The chapter is divided into the following parts. The next section presents a review of the relevant literature. Section 3 explains the treatment of donations in the German tax law. Section 4 explains empirical methodology. Section 5 presents estimation results. In Section 6, some robustness checks are presented, and Section 7 concludes.

\section{Literature}

There is a vast empirical literature investigating the tax-price and income elasticity of donations in the United States. Initial research was conducted with cross-sectional data, using ordinary least squares (OLS) or Tobit methods. Examples include Feldstein and Taylor (1976) and Feenberg (1988). The estimated price elasticity was large, on average -1.5 (United States). Later, the availability of panel data allowed researchers to exploit techniques accounting for individual heterogeneity of donors and found much lower price elasticities (for example, Broman 1989). Recently, a new line of research has tried to distinguish permanent from transitory effects using the availability of long panels (see, for example, Randolph 1995; Barrett et al. 1997; Bakija 2000). However, the discussion concerning the nature of the "true" tax-price elasticity is still ongoing.

Studies on tax-price elasticities from other countries are rather scarce, though tax deductions for donations are widely employed. Given different attitudes toward giving in different cultures as well as different roles governments play in the provision of public goods in different countries, the magnitude of the response to fiscal incentives in these countries might be very different from the United States. For example, Fack and Landais (2010), using a nonparametric method of quantile regression, found rather low elasticities for France, ranging from -0.6 to -0.2 .

There are only a few empirical studies for Germany. Pioneering work was done by Paqué (1996). Using tax data aggregated on a state and income-group basis for 1961 to 1980 in three-year intervals and using the OLS method, he found an elasticity in the range of -1.8 to -1.4. Auer and Kalusche (2010) implemented a Tobit estimator on a 1998 cross section with individual data and found an elasticity of -1.11 to -1.05 . Borgloh (2008) used a Tobit and a two-step Heckman model applied to pooled 2001-2003 individual tax data and provided estimates in the range of -2.08 to -0.84 . Two more recent studies applied a censored quantile regression. Bönke et al. (2013) used (pooled) cross sections of the years 1998, 2001, and 2004 and obtained results ranging between -1.45 and -0.45 . Bönke and Werdt (2015) used panel data for 2001-2006 and estimated heterogeneous elasticities depending on the level of donations. For donors at the lower and upper tails of the donation distribution, they estimated the price elasticity to be greater than 1 in absolute value and those in the middle of the donations distribution to be lower than 1 .

This chapter makes use of the longitudinal characteristics of the available panel data for 2001-2006. Different from Bönke and Werdt (2015), I apply a different methodology which 
allows me to control for unobserved individual characteristics. Different from early studies for Germany, changes in tax rates were implemented in the years 2004 and 2005 (see Figures 12.1 and 12.2); thus, exogenous variation in price is available.

The methods used in this chapter are most similar to Bakija and Heim (2011). They worked with a very long panel of U.S. tax returns from 1979-2006. Bakija and Heim relied on both tax changes in the federal tax law and on the differences in tax evolution between different states. In Germany, there is only one uniform tax schedule. In this chapter, tax-price elasticity can be identified because individuals with different incomes were affected differently by tax schedule changes (see Figures 12.1 and 12.2). Instead of using the so called first-dollar (first-euro) price as proxy for the actual price, I apply an instrumental variable (IV) approach using the first-dollar price as an instrument for the actual price. I take the same approach for after-tax income.

\section{Donations and the tax system in Germany}

In Germany, both individual tax liability and the treatment of donations are regulated in the German Income Tax Act (ITA). The German fiscal year is equal to the calendar year. Roughly speaking, tax liability is determined in two steps. In the first step, all income from seven sources is added together, and then different deductions are subtracted. These include allowances for the elderly and farmers, loss deduction, special expenses deduction (including donations), deduction for extraordinary expenses, and personal allowances. The remaining amount is the taxable income (TI). If a couple opts for joint declaration, the taxable income for each spouse is determined as the average of the taxable incomes of both spouses. In the second step, the tax due is computed. The formula is $T A X=a_{i} T I^{2}+b_{i} T I+c_{i}$, where $i=0,1,2,3$ defines different income thresholds such that this function is continuous but not smooth. Marginal tax is then given by $M T=2 a_{i} T I+b_{i}$. Figure 12.2 presents the marginal tax as a function of taxable income for a single household in 2001-2006. A tax reform was implemented gradually in 2004 and 2005, lowering the marginal tax for all incomes but to a different extent. Figure 12.2 shows the changes in the tax-price for individuals with different values of taxable income. It indicates that individuals with $€ 10,000, € 30,000$, and $€ 60,000$ taxable income experience a larger increase in the tax-price than, for example, individuals with $€ 50,000$ taxable income.

\section{Marginal tax}

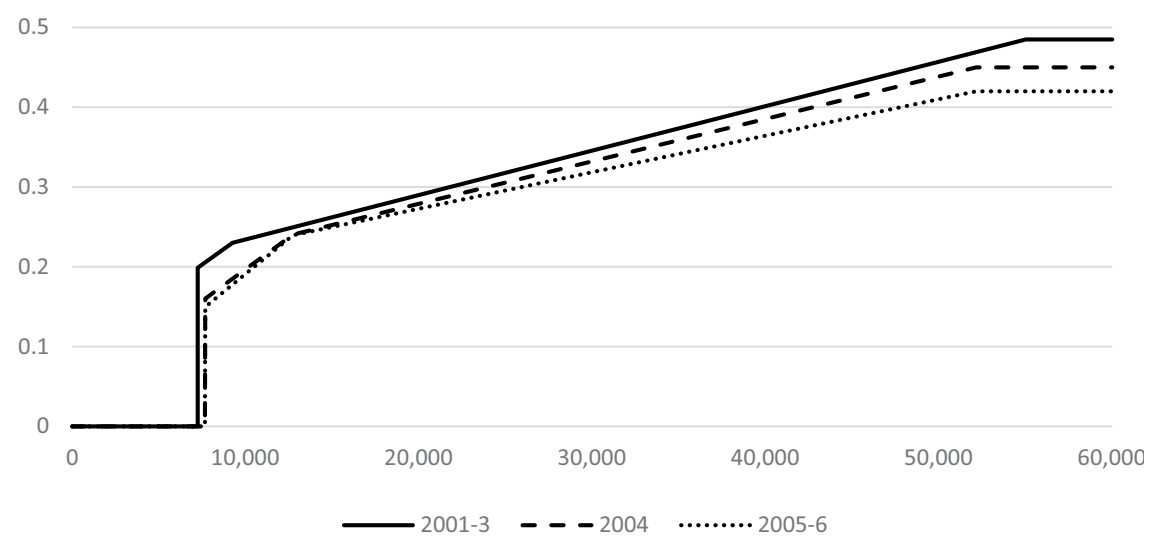

Figure 12.1 Marginal tax rates 2001-2006, single 


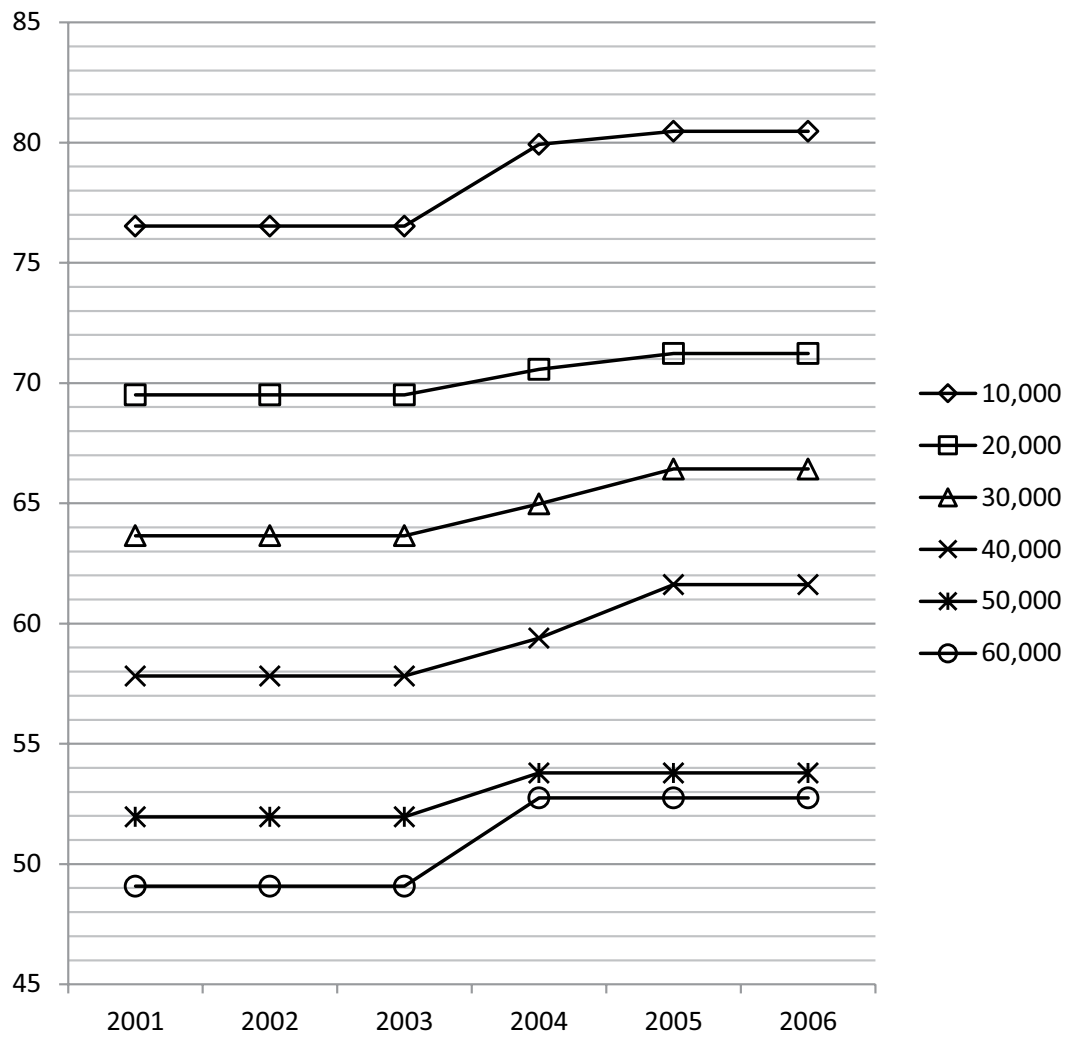

Figure 12.2 The evolution of the tax-price 2001-2006 for different values of taxable income per $€ 100$ (single)

The deductibility of donations is regulated in $\$ 10 \mathrm{~b}$ and $\$ 34 \mathrm{~g}$ ITA. $\$ 10 \mathrm{~b}$ addresses donations and membership fees to organizations that pursue scientific, charitable and cultural goals that are recognized as eligible. These are deductible up to an amount $5 \%$ of gross income. Furthermore, $\$ 10 \mathrm{~b}$ allows deductions of donations and membership fees to organizations pursuing churchrelated, religious, and charitable goals that are recognized as eligible. These are deductible up to an additional $5 \%$ of gross income. Additionally, one can deduct donations to foundations up to $€ 20,450$ and grants to newly established foundations up to $€ 307,000$. Donations to political parties are governed by $\$ 34 \mathrm{~g}$ and $\$ 10 \mathrm{~b}$ ITA. Fifty percent of the first $€ 1,650$ (singles) or $€ 3,300$ (married) given is directly deducted from due tax, having thus a fixed price of 0.5 for each $€ 1$ given. Each euro donated above this threshold up to $€ 3,300$ (singles) or $€ 6,600$ (married) reduces the taxable income in keeping with $\$ 10 \mathrm{~b}$. The price of those donations is given by 1 minus the marginal tax. In the following sections, I will focus specifically on those donations which can be deducted from gross income, the price of which is given by 1 minus the marginal tax. ${ }^{10}$

Among different separate deductions, German law allows for the deduction of extraordinary expenses $(\$ 10, \$ 10 \mathrm{a}$ ITA). These include childcare, tax advice, alimony and other ongoing financial obligations, deductible church tax, education and training, expenses of a provident nature, school tuitions, donations, and other. Those who do not itemize any of those obtain a blanket allowance of $€ 36$ ( $€ 72$ for couples choosing joint declaration). 
Sommerfeld (2009) provided a statistical overview of charitable giving in Germany. Her survey revealed that $83.5 \%$ of taxpayers are aware of the deductibility of donations. According to Sommerfeld, $70 \%$ of the population donates and $43 \%$ declare donations in tax declarations.

\section{Empirical methodology}

\subsection{Empirical specification}

Usually, the literature assumes that the demand function for donations, $D O N=f((1-\tau), Y)$, is linear in a natural logarithm and imposes the following empirical specification: ${ }^{11}$

$$
\ln D O N_{i}=\mu+\delta \ln \left(1-\tau_{i}\right)+\beta \ln Y_{i}+X_{i} \gamma+u_{i}
$$

where for each individual $i, D O N_{i}$ is the amount of the donations, $\tau_{i}$ is the marginal tax, $Y_{i}$ is a measure of disposable income, $X_{i}$ is a vector of other characteristics, ${ }^{12} \mu$ is some constant, and $u_{i}$ is an error term. Given the nonlinear dependence of the right-hand-side variables, that is, tax-price, income, marital status, and other characteristics leading to different deductions, there is the serious risk that if equation 1 is misspecified, the coefficients of interest might not be identified. The issues that accompany attempts to determine the tax-price effect and the income effect separately are discussed in Triest (1998). Identification is only possible if there is a variation in tax rates (price) independent of individual characteristics that may affect charitable giving. Feenberg's (1988) solution is to exploit the variations in state income taxes in the United States. For Germany, there is only one national income tax law. The needed variation in price is provided because changes in national income tax occurred in 2004 and 2005, and they affected individuals with different incomes differently (see Figure 12.2). Adopting the widespread approach from the previous literature on charitable giving, and in order to interpret the coefficients directly as elasticities, I estimate the previous log-log specification with some modifications explained in the following.

One of the most important issues is the omitted variable bias. The available data are missing characteristics such as education, wealth, and altruism which are known to be important determinants of charitable giving. ${ }^{13}$ Likewise, these variables are known to be correlated with income. ${ }^{14}$ Given that, a simple regression analysis will not identify the parameters of interest. Therefore, in the donation equation, I account for the individual-specific fixed effects $\alpha_{i}$. I assume that these individual-specific fixed effects $\alpha_{i}$ do not vary (significantly) ${ }^{15}$ over time. However, these fixed (time-invariant) individual-specific effect are potentially correlated with other explanatory variables, that is, $E\left\{X_{i t} \alpha_{i}\right\} \neq 0$. To account for factors influencing donations from year to year, the time fixed effects $\delta_{t}$ are included in the specification. This might be especially important, as the Elbe flooding happened in 2002 and the tsunami at the end of 2004 , thus increasing donations shortly afterwards. The time-varying, individual-specific error term denoted as $u_{i t}$. I assume that $E\left\{X_{i t} u_{i t}\right\}=0$ for each $t$. The donation equation becomes:

$$
\operatorname{lnDON} N_{i t}=\delta \ln P R I C E_{i t}+\beta \ln Y_{i t}+X_{i t} \gamma+\alpha_{i}+\delta_{t}+u_{\text {iो }}
$$

The next important issue concerns endogeneity. Clearly, the tax-price is determined by income, marital status, the amount donated, and other deductions. For many levels of income, it holds true that the higher the amount of donations, the lower the marginal tax rate, and consequently the higher the tax-price. Similarly, after-tax income depends on taxes, which in 
turn depends on the amount donated. The simple OLS estimation of the equation of interest would yield biased estimates. Here, I address the endogeneity by using an instrumental variable estimator. For each individual, I calculate a hypothetical marginal tax at zero donations, which is clearly uncorrelated with the dependent variable. Similarly, for after-tax income, I calculate a hypothetical after-tax income at zero donations. Those instruments are correlated with the endogenous variables but uncorrelated with unobserved characteristics which determine donations. There is a convention in the literature on charitable giving of regressing donations directly onto these hypothetical variables, which are usually called first-dollar price and first-dollar income. This seems to be the second-best approach when the IV method is feasible. Not taking the IV approach leads to the estimation of what may be termed "first-dollar price elasticity." But this will be different from the actual tax-price elasticity, especially because first-dollar price elasticity is measured at a lower quantity and a lower price.

In the data, a significant portion of taxpayers do not itemize. Clotfelter (1980), Boskin and Feldstein (1977), and Reece and Zieschang (1985) suggest that excluding nonitemizers and border itemizers ${ }^{16}$ might lead to a selection bias. Therefore, I follow Feldstein and Taylor (1976) by calculating a modified first-euro price as if the itemization were possible regardless of the actual value of donation. ${ }^{17}$ This first-euro price is used in the IV approach as an instrument for the actual price, which is strictly lower than one for border itemizers and differs for each individual. I proceed accordingly for nonitemizers.

Many donors do not report donations in their tax declarations. It is difficult to account for censoring and fixed effects at the same time. ${ }^{18}$ Panel studies from the United States widely employ demeaning or first differencing, for example, Bakija (2000) or Randolph (1995), and I follow this approach. Nonetheless, I will compare my results from the estimation of equation 2 with the results from an estimation that accounts for censoring in Section 6.3.

The availability of a six-year panel allows me to identify permanent and transitory effects. Therefore, specification 2 is extended to:

$$
\begin{aligned}
\operatorname{lnDON}_{i t} & =\delta_{1} \ln P R I C E_{i t-1}+\delta_{2} \ln P R I C E_{i t}+\delta_{3} \ln P R I C E_{i t+1}+ \\
& +\beta_{1} \ln Y_{i t-1}+\beta_{2} \ln Y_{i t}+\beta_{3} \ln Y_{i t+1}+ \\
& +X_{i t} \gamma+\alpha_{i}+\delta_{t}+u_{i t} .
\end{aligned}
$$

The permanent price effect is given by $\delta_{1}+\delta_{2}+\delta_{3}$, the transitory effect by $\delta_{2}$, and the effect of an anticipated increase in price next year by $\delta_{3} \cdot{ }^{19}$ Similarly, the permanent income effect is given by $\beta_{1}+\beta_{2}+\beta_{3}$ and the transitory income effect by $\beta_{\text {, }}$, respectively. When the actual values for the future tax-price and income are included into the equation 3, one assumes perfect foresight. However, future expectations are what matters for charitable giving and not realizations. To address this caveat, I implement a similar solution to the one chosen by Bakija and Heim (2011). In one specification (perfect foresight), I treat future realizations of price and income as erroneous measurements of future expectations. In an alternative specification (predictable tax change), I implement the IV approach in which I assume that the tax formula of the following year is known but one's own income in the following year is not known. This means that in the first step, I predict the following year's income using broad information available about the subjects, especially the income and price from the year in question and the year before as covariates. In the second step, I use this predicted income to calculate the (predicted) future after-tax-income and the (predicted) future price using the appropriate tax formula.

Finally, to allow for heterogeneous effects of price and nonprice variables, I multiply them by dummies for four different income classes (gross income in €: 1-29,999; 30,000-59,999; 
60,000-89,999; and $\geq 90,000$ for single households and twice the amount for married couples). Recall that the price is based on taxable income, which might be very different from the gross income. This means that the income groups are rather based on status than on disposable income and price. If there is indeed heterogeneity, the last step is also necessary due to the selectivity of the available sample in which high-income taxpayers are overrepresented (see the data description subsequently). Therefore, specification 3 is extended to:

$$
\begin{aligned}
\ln D O N_{i t}= & \sum_{j=1}^{4} D_{j}^{*} \\
& *\left[\delta_{j 1} \ln P R I C E_{i t-1}+\delta_{j 2} \ln P R I C E_{i t}+\delta_{j 3} \ln P R I C E_{i t+1}+\right. \\
& \left.+\beta_{j 1} \ln Y_{i t-1}+\beta_{j 2} \ln Y_{i t}+\beta_{j 3} \ln Y_{i t+1}+X_{i t} \gamma_{j}+\delta_{j t}\right]+ \\
& +\alpha_{i}+u_{i t},
\end{aligned}
$$

where $D_{j}$ are dummies for the four income groups $j=\{1,2,3,4\}$. This approach allows, moreover, for a more flexible relationship between income and charitable giving, thus relaxing the assumption imposed by equation 1 .

\subsection{Data}

The analysis in this chapter is based on $5 \%$ stratified sample from the German Taxpayer Panel 2001-2006 made available by the German Federal Statistical Office. It is a rich panel of individual income tax return data in which high-income taxpayers are strongly overrepresented. The strata are based on region, joint or separate declaration, main income source, and the average of the gross income over the six years. It contains around a million observations per year, detailed information on income and taxes, and some demographic characteristics such as age, state of residence, religion, and the number and age of children. The panel is available for distant computations with SAS. Tables 12.1 and 12.2 present some descriptive statistics.

\subsection{Variables}

The dependent variable, $\ln \left(D O N_{i t}+1\right)$, is the natural logarithm of donations declared according to $\$ 10 \mathrm{bITA}$. Given that there are households that do not declare any donations and in order to assure that this variable takes values larger than zero, I add $€ 1$ to the amount of donations. The U.S. literature usually adds the amount of $\$ 10$. However, the average donation in those studies is 5 to more than 250 times higher than in the data used for this study. ${ }^{20}$ This suggests that $€ 1$ is a better choice. However, the choice is still arbitrary. Later, I present robustness checks adding, alternatively, $€ 5$ and $€ 10$ to the amount of donations.

The first independent variable, $\ln P R I C E_{i t}$, is the natural logarithm of the price, which is 1 minus the marginal tax rate. The actual tax rate is endogenous, as it changes with the amount donated. Therefore, I calculate for each individual a hypothetical marginal tax at zero donations and use its natural logarithm, ${ }^{\text {In } \widetilde{K I C E} \text { it }}$, as an instrument.

The second independent variable, $\ln Y_{i t}$, is the natural logarithm of the after-tax income. Respectively, I calculate a hypothetical after-tax income at zero donations and use its natural logarithm, $\ln \tilde{Y}_{i t}$, as an instrument.

Additionally, I include other control variables: dummies for each of the six income sources other than income earned as an employee (income from agriculture and forestry, from business, 
Table 12.1 Descriptive statistics 1

\begin{tabular}{cllllll}
\hline & 2001 & 2002 & 2003 & 2004 & 2005 & 2006 \\
\hline Avg. donation & 474.73 & 537.54 & 511.34 & 580.72 & 647.77 & 665.48 \\
$(€)$ & $(118.99)$ & $(133.24)$ & $(127.57)$ & $(140.57)$ & $(153.31)$ & $(147.39)$ \\
Donor share & 45.55 & 47.64 & 46.75 & 48.77 & 50.34 & 47.71 \\
$(\%)$ & $(34.70)$ & $(36.98)$ & $(35.89)$ & $(37.88)$ & $(38.93)$ & $(36.55)$ \\
Avg. price (per & 71.03 & 71.32 & 71.36 & 72.20 & 72.03 & 72.85 \\
100€) & $(75.09)$ & $(75.02)$ & $(75.05)$ & $(74.76)$ & $(74.97)$ & $(74.95)$ \\
Avg. gross & 80,287 & 76,677 & 76,018 & 82,302 & 92,919 & 96,941 \\
income (€) & $(33,344)$ & $(33,272)$ & $(33,297)$ & $(34,531)$ & $(33,346)$ & $(36,753)$ \\
Avg. age & 47.20 & 48.18 & 49.17 & 50.16 & 51.16 & 52.15 \\
& $(44.10)$ & $(45.09)$ & $(46.08)$ & $(47.07)$ & $(48.07)$ & $(49.06)$ \\
Joint declaration & 60.30 & 60.53 & 60.71 & 60.86 & 61.12 & 61.06 \\
share (\%) & $(57.77)$ & $(57.97)$ & $(58.23)$ & $(58.55)$ & $(58.72)$ & $(58.76)$ \\
West share (\%) & 84.77 & 84.79 & 84.80 & 84.83 & 84.85 & 84.87 \\
Religion share & $(85.35)$ & $(85.34)$ & $(85.32)$ & $(85.31)$ & $(85.30)$ & $(85.31)$ \\
$\quad(\%)$ & $(23.08)$ & $(23.09)$ & $(23.00)$ & $(22.72)$ & $(22.33)$ & $(23.21)$ \\
Self-employ- & 18.13 & 18.26 & 18.50 & 18.77 & 18.86 & 18.77 \\
ment share $(\%)$ & $(6.36)$ & $(6.40)$ & $(6.53)$ & $(6.75)$ & $(6.85)$ & $(6.93)$ \\
Number of & 0.82 & 0.81 & 0.80 & 0.79 & 0.78 & 0.76 \\
children & $(0.75)$ & $(0.75)$ & $(0.74)$ & $(0.73)$ & $(0.72)$ & $(0.71)$ \\
N in million & 0.93 & 0.93 & 0.93 & 0.93 & 0.93 & 0.93 \\
\hline
\end{tabular}

Note: This table presents raw sample averages. Population weighted averages are presented in brackets.

Table 12.2 Descriptive statistics 2

\begin{tabular}{lcccc}
\hline Single & & & & \\
Gross income $(€)$ & $1-29,999$ & $30,000-59,999$ & $60,000-89,999$ & $\geq 90,000$ \\
Avg. price & 99.59 & 76.13 & 62.03 & 55.45 \\
$N$ in millions (total 6 years) & 0.37 & 0.93 & 0.35 & 0.37 \\
Joint declaration & & & & $\geq 180,000$ \\
Gross income ( $€$ Avg. price & $1-59,999$ & $60,000-119,999$ & $120,000-179,999$ & 54.80 \\
$N$ in millions (total 6 years) & 99.66 & 73.21 & 61.12 & 1.09 \\
\hline
\end{tabular}

Note: This table presents raw sample averages.

from self-employment, from dependent employment, capital income, and from rent and leasing properties), a dummy for joint declaration, for living in West Germany, for religious affiliation, and one control variable for the number of children and for the age squared. Note that as those controls seldom change over time, they are mostly absorbed by individual fixed effects.

\section{Estimation results}

Table 12.3 presents the results from the estimation, which allows the coefficients for all nonprice variables to differ across income classes and uses the IV approach to price and income. The estimates for permanent price elasticity are -0.57 (Table 12.3, column I) assuming perfect foresight and -0.82 (Table 12.3, column II) when relying on predictable changes of future income and price. 
Table 12.3 Permanent and transitory effects: the estimation allows coefficients on all nonprice variables to differ across income classes using the IV approach to price and income. The dependent variable is $\ln D O N_{i, t}$

\begin{tabular}{|c|c|c|c|c|c|c|c|c|}
\hline & \multicolumn{4}{|c|}{ (I) Perfect foresight } & \multicolumn{4}{|c|}{ (II) Predictable tax change instruments } \\
\hline $\ln P R I C E_{i, t}$ & \multicolumn{4}{|c|}{$\begin{array}{l}-0.14 \star \star \star \\
(0.01)\end{array}$} & \multicolumn{4}{|c|}{$\begin{array}{r}-0.01 \\
(0.01)\end{array}$} \\
\hline $\ln P R I C E_{i, t-1}$ & \multicolumn{4}{|c|}{$\begin{array}{l}-0.33 \star \star \star \\
(0.01)\end{array}$} & \multicolumn{4}{|c|}{$\begin{array}{l}-0.41 \star \star \star \\
(0.02)\end{array}$} \\
\hline $\ln P R I C E_{i, t+1}$ & \multicolumn{3}{|c|}{$-0.10^{\star \star}$} & $(0.01)$ & \multicolumn{4}{|c|}{$(0.04)$} \\
\hline $\begin{array}{l}\text { Permanent price } \\
\text { elasticity }\end{array}$ & \multicolumn{4}{|c|}{-0.57} & \multicolumn{4}{|c|}{-0.82} \\
\hline Income class & $1-29,999$ & $\begin{array}{r}30,000- \\
59,999\end{array}$ & $\begin{array}{r}60,000- \\
89,999\end{array}$ & $\geq 90,000$ & $1-29,999$ & $\begin{array}{r}30,000- \\
59,999\end{array}$ & $\begin{array}{r}60,000- \\
89,999\end{array}$ & $\geq 90,000$ \\
\hline $\ln Y_{i, t}$ & $\begin{array}{l}0.19 \star \star \star \\
(0.00)\end{array}$ & $\begin{array}{l}0.16 \star \star \star \\
(0.00)\end{array}$ & $\begin{array}{l}0.16 \star \star \star \\
(0.00)\end{array}$ & $\begin{array}{l}0.15 \star \star \star \\
(0.00)\end{array}$ & $\begin{array}{l}0.26 \star \star \star \\
(0.01)\end{array}$ & $\begin{array}{l}0.23 \star \star \star \\
(0.01)\end{array}$ & $\begin{array}{l}0.22 \star \star \star \\
(0.01)\end{array}$ & $\begin{array}{l}0.21 \star \star \star \\
(0.01)\end{array}$ \\
\hline $\ln Y_{i, t-1}$ & $\begin{array}{l}0.00 \\
(0.00)\end{array}$ & $\begin{array}{l}0.01 \star \\
(0.00)\end{array}$ & $\begin{array}{l}0.01 \star \\
(0.00)\end{array}$ & $\begin{array}{l}0.01 \star \star \star \\
(0.00)\end{array}$ & $\begin{array}{l}-0.01 \star \\
(0.01)\end{array}$ & $\begin{array}{l}-0.01 \\
(0.01)\end{array}$ & $\begin{array}{l}-0.01 \\
(0.01)\end{array}$ & $\begin{array}{l}-0.00 \\
(0.01)\end{array}$ \\
\hline $\ln Y_{i, t+1}$ & $\begin{array}{l}0.04 \star \star \star \\
(0.00)\end{array}$ & $\begin{array}{l}0.03 \star \star \star \\
(0.00)\end{array}$ & $\begin{array}{l}0.04 \star \star \star \\
(0.00)\end{array}$ & $\begin{array}{l}0.04 \star \star \star \\
(0.00)\end{array}$ & $\begin{array}{l}0.08 \star \star \\
(0.02)\end{array}$ & $\begin{array}{l}0.08 \star \star \\
(0.02)\end{array}$ & $\begin{array}{l}0.08 \star \star \\
(0.02)\end{array}$ & $\begin{array}{l}0.08 \star \star \\
(0.02)\end{array}$ \\
\hline $\begin{array}{l}\text { Permanent income } \\
\text { elasticity }\end{array}$ & 0.23 & 0.20 & 0.20 & 0.31 & 0.34 & 0.31 & 0.30 & 0.28 \\
\hline $\begin{array}{l}\text { Other controls } \times \\
\text { income class }\end{array}$ & \multicolumn{4}{|c|}{ Yes } & \multicolumn{4}{|c|}{ Yes } \\
\hline $\begin{array}{l}\text { year effects } \times \text { income } \\
\text { class }\end{array}$ & \multicolumn{4}{|c|}{ Yes } & \multicolumn{4}{|c|}{ Yes } \\
\hline fixed individual effects & \multicolumn{4}{|c|}{ Yes } & \multicolumn{4}{|c|}{ Yes } \\
\hline$N$ in millions & \multicolumn{4}{|c|}{3.36} & \multicolumn{4}{|c|}{2.72} \\
\hline
\end{tabular}

Source: Taxpayerpanel 2001-2006, author's own calculations

Notes: Standard errors in parentheses

$\star \star \star$ Significant at 0.01 level, $\star \star$ significant at 0.05 level, $\star$ significant at 0.1 level

The estimates for permanent income elasticity are around $0.2-0.3$, slightly varying among different income classes. The estimates of price elasticity are rather low when compared with previous crosssectional studies from Germany. ${ }^{21}$ However, if the price elasticity differs among income groups, those estimates are rather meaningless and depend strongly on the composition of the sample. Therefore, in the next table, we move on to relaxing the assumption of homogeneity of price elasticity.

Table 12.4 presents the results from the estimation, which allows the coefficients on all variables to differ across income classes (equation 4) and uses the IV approach to price and income. It allows for the heterogeneity of tax responsiveness among different income groups and corrects for the sample composition in which high income groups are overrepresented. The results show that permanent tax-price elasticity varies significantly between income classes. It is as low as -0.26 (perfect foresight) and -0.17 (predictable changes) for pretax incomes below $€ 30,000$ for singles and $€ 60,000$ for married couples, respectively. It is as high as -1.40 (perfect foresight) and -1.56 (predictable changes) for incomes $€ 30,000-59,999$ for singles and 
Table 12.4 Permanent and transitory effects. Estimates allowing coefficients on all variables including price to differ across income classes. IV approach to price and income. Dependent variable: $\ln D O N_{i, t}$.

\begin{tabular}{|c|c|c|c|c|c|c|c|c|}
\hline \multirow[b]{2}{*}{ income class } & \multicolumn{4}{|c|}{ (I) Perfect foresight } & \multicolumn{4}{|c|}{ (II) Predictable tax change instruments } \\
\hline & $1-29,999$ & $\begin{array}{r}30,000- \\
59,999\end{array}$ & $\begin{array}{r}60,000- \\
89,999\end{array}$ & $\geq 90,000$ & $1-29,999$ & $\begin{array}{r}30,000- \\
59,999\end{array}$ & $\begin{array}{r}60,000- \\
89,999\end{array}$ & $\geq 90,000$ \\
\hline $\ln P R I C E_{i, t}$ & $\begin{array}{c}-0.01 \\
\quad(0.01)\end{array}$ & $\begin{array}{c}-0.54 \star \star \star \\
(0.03)\end{array}$ & $\begin{array}{c}-0.38 \star \star \star \\
(0.04)\end{array}$ & $\begin{array}{c}-0.37 \star \star \star \\
(0.04)\end{array}$ & $\begin{array}{r}0.24 \star \star \star \\
(0.02)\end{array}$ & $\begin{array}{c}-0.41 \star \star \star \\
(0.04)\end{array}$ & $\begin{array}{c}-0.37 \star \star \star \\
(0.07)\end{array}$ & $\begin{array}{c}-0.48^{\star \star \star} \\
(0.05)\end{array}$ \\
\hline $\ln P R I C E_{i, t-1}$ & $\begin{array}{c}-0.23 \star \star \star \\
(0.01)\end{array}$ & $\begin{array}{c}-0.47 \star \star \star \\
(0.03)\end{array}$ & $\begin{array}{c}-0.51 \star \star \star \\
(0.04)\end{array}$ & $\begin{array}{c}-0.71 \star \star \star \\
(0.03)\end{array}$ & $\begin{array}{c}-0.22^{\star \star \star} \\
(0.02)\end{array}$ & $\begin{array}{c}-0.57 \star \star \star \\
(0.03)\end{array}$ & $\begin{array}{c}-0.65 \star \star \star \\
(0.05)\end{array}$ & $\begin{array}{c}-0.89 \star \star \star \\
(0.04)\end{array}$ \\
\hline $\ln P R I C E_{i, t+1}$ & $\begin{array}{r}-0.03 \star \star \\
(0.01)\end{array}$ & $\begin{array}{c}-0.38 \star \star \star \\
(0.03)\end{array}$ & -0.06 & $\begin{array}{l}0.01 \\
\quad(0.03)\end{array}$ & $\begin{array}{c}-0.19 \star \star \star \\
(0.05)\end{array}$ & $\begin{array}{c}-0.58 \star \star \star \\
(0.07)\end{array}$ & $\begin{array}{c}-0.32^{\star \star \star} \\
(0.07)\end{array}$ & $\begin{array}{l}0.01 \\
\quad(0.06)\end{array}$ \\
\hline $\begin{array}{l}\text { Permanent } \\
\text { price } \\
\text { elasticity }\end{array}$ & -0.26 & -1.40 & -0.96 & -1.07 & -0.17 & 1.56 & -1.33 & -1.38 \\
\hline $\ln Y_{i, t}$ & $\begin{array}{r}0.21 \star \star \star \\
(0.00)\end{array}$ & $\begin{array}{r}0.16^{\star \star \star} \\
(0.00)\end{array}$ & $\begin{array}{r}0.16^{\star \star \star} \\
(0.00)\end{array}$ & $\begin{array}{r}0.15 \star \star \star \\
(0.00)\end{array}$ & $\begin{array}{r}0.31 \star \star \star \\
(0.01)\end{array}$ & $\begin{array}{r}0.25 \star \star \star \\
(0.01)\end{array}$ & $\begin{array}{r}0.24 \star \star \star \\
(0.01)\end{array}$ & $\begin{array}{r}0.23 \star \star \star \\
(0.01)\end{array}$ \\
\hline $\ln Y_{i, t-1}$ & $\begin{array}{r}0.01 \star \star \star \\
(0.00)\end{array}$ & $\begin{array}{l}0.01^{\star} \\
(0.00)\end{array}$ & $\begin{array}{l}0.01^{\star} \\
(0.00)\end{array}$ & $\begin{array}{c}-0.00 \\
(0.00)\end{array}$ & $\begin{array}{l}0.01 \\
\quad(0.01)\end{array}$ & $\begin{array}{c}-0.00 \\
(0.01)\end{array}$ & $\begin{array}{r}-0.01 \\
\quad(0.01)\end{array}$ & $\begin{array}{r}-0.02^{\star \star} \\
(0.01)\end{array}$ \\
\hline $\ln Y_{i, t+1}$ & $\begin{array}{r}0.04 \star \star \star \\
(0.00)\end{array}$ & $\begin{array}{r}0.03 \star \star \star \\
(0.00)\end{array}$ & $\begin{array}{r}0.04 \star \star \star \\
(0.00)\end{array}$ & $\begin{array}{r}0.05 \star \star \star \\
(0.00)\end{array}$ & $\begin{array}{r}0.07 \star \star \\
(0.02)\end{array}$ & $\begin{array}{r}0.05^{\star \star} \\
(0.02)\end{array}$ & $\begin{array}{r}0.06^{\star \star} \\
(0.02)\end{array}$ & $\begin{array}{r}0.08^{\star \star \star} \\
(0.02)\end{array}$ \\
\hline $\begin{array}{l}\text { Permanent } \\
\text { income } \\
\text { elasticity }\end{array}$ & 0.27 & 0.19 & 0.21 & 0.20 & 0.39 & 0.30 & 0.30 & 0.29 \\
\hline $\begin{array}{l}\text { Other controls } \\
\times \text { income } \\
\text { class }\end{array}$ & & & Yes & & & & Yes & \\
\hline $\begin{array}{l}\text { year effects } \\
\quad \times \text { income } \\
\text { class }\end{array}$ & & & Yes & & & & Yes & \\
\hline $\begin{array}{l}\text { fixed } \\
\text { individual } \\
\text { effects }\end{array}$ & & & Yes & & & & Yes & \\
\hline$N$ in millions & & & 36 & & & & .72 & \\
\hline
\end{tabular}

Source: Taxpayerpanel 2001-2006, author's own calculations

Notes: Standard errors in parentheses

$\star \star \star$ Significant at 0.01 level, $\star \star$ significant at 0.05 level, $\star$ significant at 0.1 level

$€ 60,000-119,999$ for married couples. Higher incomes show elasticity of around -1 when assuming perfect foresight and around -1.35 when assuming predictable changes. Overall, there is evidence of heterogeneity among income classes. Consequently, this table presents results from the preferred specification (equation 4), and the results are referred to in conclusions from this chapter. Given that the distribution of the income classes in the whole population is approximately $50 \%, 30 \%, 10 \%$, and $10 \%$, and their shares of total giving are $23 \%, 26 \%$, $14 \%$, and $37 \%,{ }^{22}$ the average weighted permanent elasticity is slightly below -1 . Overall, one can judge the fiscal incentives in Germany as being effective in stimulating charitable giving. However, the results also show that different treatment of donors depending on their characteristics could improve the efficiency even more. This could lead to a potential further decoupling of the price for charitable giving from the tax scheme. 
The comparability with other empirical studies for Germany is limited because they all estimate "first-euro" elasticity. Regardless of the differences in the definition, my estimates predict rather lower responsiveness to tax incentives. This is especially true with respect to previous studies relying on OLS and Tobit methods.

The estimates for permanent income elasticity are around $0.2-0.3$, slightly varying among different income classes.

I find evidence that donors adjust their charitable contributions gradually. They respond strongly to the former price. Moreover, I find evidence for all income classes, apart from the highest, that donors respond to predictable future changes in the price (see Table 12.4). The actual income and to some extent the future income drive the donations. The effects of past income are negligible.

\section{Robustness checks}

This section presents a number of important robustness checks.

\subsection{Assuming that coefficients are uniform across income classes}

Table 12.5 presents the results from a regression when assuming that all coefficients are uniform across income classes (equation 3) and using the IV approach to price and income. Column I presents the results from a regression that assumes perfect foresight, and column II presents the results when using predictable-tax-change instruments. The coefficient estimates of permanent price elasticity $(-0.33$ and -0.37$)$ are low in magnitude when compared to the estimates from cross-sectional studies estimating a uniform price elasticity for Germany. Similarly, the coefficient estimates for permanent income elasticity (0.31 and 0.43) are rather low. However, given the selectivity of the available sample, those results cannot be carried over to the whole population. More importantly, the conclusions from Tables 12.1 and 12.2 are that the assumption of homogeneity among different income classes is clearly violated. This table, however, is the basis for the comparisons with the subsequent robustness checks.

Table 12.5 Permanent and transitory effects: assuming coefficients are uniform across income classes, using the IV approach to price and income. The dependent variable is $\ln D O N_{i, t}$

\begin{tabular}{|c|c|c|}
\hline & (I) Perfect foresight & (II) Predictable tax change instruments \\
\hline $\ln P R I C E_{i, t}$ & $-0.03 \star \star(0.01)$ & $0.05^{\star \star}(0.02)$ \\
\hline $\ln P R I C E_{i, t-1}$ & $-0.33^{\star \star \star}(0.01)$ & $-0.43^{\star \star \star}(0.02)$ \\
\hline $\ln P R I C E_{i, t+1}$ & $0.02 \star \star(0.01)$ & $0.01(0.03)$ \\
\hline Permanent price elasticity & -0.33 & -0.37 \\
\hline $\ln Y_{i, t}$ & $0.21 \star \star \star(0.00)$ & $0.26^{\star \star \star}(0.01)$ \\
\hline $\ln Y_{i, t-1}$ & $0.02 \star \star \star(0.00)$ & $0.02^{\star \star}(0.01)$ \\
\hline $\ln Y_{i, t+1}$ & $0.07 \star \star \star(0.00)$ & $0.15^{\star \star \star}(0.02)$ \\
\hline Permanent income elasticity & 0.31 & 0.43 \\
\hline Other controls & Yes & Yes \\
\hline Year effects & Yes & Yes \\
\hline Fixed individual effects & Yes & Yes \\
\hline$N$ in millions & 3.36 & 2.72 \\
\hline
\end{tabular}

Source: Taxpayerpanel 2001-2006, author's own calculations

Notes: Standard errors in parentheses

$\star \star \star$ Significant at 0.01 level, $\star \star ~ s i g n i f i c a n t$ at 0.05 level, ${ }^{\star}$ significant at 0.1 level 
Table 12.6 Permanent and transitory effects. Assuming coefficients are uniform across income classes. First-dollar price. Dependent variable: $\ln D O N_{i, t}$

\begin{tabular}{|c|c|c|}
\hline & (I) Perfect foresight & (II) Predictable tax change instruments \\
\hline $\ln P R I C E_{i, t}$ & $-0.22^{\star \star \star}(0.01)$ & $-0.30 \star \star \star(0.01)$ \\
\hline $\ln P R I C E_{i, t-1}$ & $-0.38^{\star \star \star}(0.01)$ & $-0.55^{\star \star \star}(0.01)$ \\
\hline $\ln P R I C E_{i, t+1}$ & $0.00(0.01)$ & $-0.10^{\star \star \star}(0.01)$ \\
\hline Permanent price elasticity & -0.59 & -0.95 \\
\hline $\ln Y_{i, t}$ & $0.17 \star \star \star(0.00)$ & $0.18 \star \star \star(0.00)$ \\
\hline $\ln Y_{i, t-1}$ & $0.02 \star \star \star(0.00)$ & $-0.01 \star \star \star(0.00)$ \\
\hline $\ln Y_{i, t+1}$ & $0.06 \star \star \star(0.00)$ & $0.03 \star \star \star(0.00)$ \\
\hline Permanent income elasticity & 0.25 & 0.20 \\
\hline Other controls & Yes & Yes \\
\hline Year effects & Yes & Yes \\
\hline Fixed individual effects & Yes & Yes \\
\hline$N$ in millions & 3.36 & 2.73 \\
\hline
\end{tabular}

Source: Taxpayerpanel 2001-2006, author's own calculations

Notes: Standard errors in parentheses

$\star \star \star$ Significant at 0.01 level, $\star \star$ significant at 0.05 level, $\star$ significant at 0.1 level

\subsection{First-euro price and income instead of IV approach}

Table 12.6 presents the results when estimating the basic specification (assuming coefficients are uniform across income classes) without the IV approach and using the first-euro price and, similarly, hypothetical after-tax income at zero donations instead. The estimates of permanent tax-price elasticity are higher in absolute terms when compared to the basic specification with the IV approach (Table 12.5). It changes from -0.33 to -0.59 when assuming perfect foresight and from -0.37 to -0.95 when assuming predictable tax change instruments. This might suggest that the estimates of tax-price elasticity from previous studies for Germany are overestimated. The estimates for permanent income elasticity are somewhat lower, changing from 0.31 to 0.25 when assuming perfect foresight and from 0.43 to 0.20 when assuming predictable tax change instruments.

\subsection{Censoring}

Because I do not observe donations for around $50 \%$ of observations, there is a serious concern that due to censoring, my confidents are biased. Can the comparably low coefficient estimates of price elasticity be explained by neglecting the censoring? I estimate a Tobit model ${ }^{23}$ on pooled data regressing donations directly on the first-euro price and other variables. I then compare the results with analogous OLS regression which does not account for censoring. The estimated coefficients as compared to simple OLS regression on pooled data are presented in Table 12.7. The marginal effects from the Tobit regressions are similar to those obtained from the OLS estimation. This does not support the hypothesis that the estimates of the elasticity obtained in previous sections are seriously biased due to censoring.

\subsection{Adding different amounts to donations}

Because of the numerous observations with zero donations and because the logarithmic function is not defined at zero, I have added an additional euro to the individual contribution. 
Table 12.7 Accounting versus not accounting for censoring: Tobit versus OLS. First-euro price. Assuming perfect foresight. Dependent variable: $\ln D O N_{i, t}$

\begin{tabular}{|c|c|c|c|c|}
\hline & Tobit marginal effects & OLS & Tobit marginal effects & OLS \\
\hline $\ln P R I C E_{i, t}$ & $-1.16^{\star \star \star}(0.24)$ & $-1.11 \star \star \star(0.03)$ & $-0.60 \star \star \star(0.11)$ & $-0.68^{\star \star \star}(0.08)$ \\
\hline $\ln P R I C E_{i, t-1}$ & & & $-0.41 \star \star \star(0.07)$ & $-0.58^{\star \star \star}(0.06)$ \\
\hline $\ln P R I C E_{i, t+1}$ & & & $-0.14 \star \star \star(0.02)$ & $-0.18^{\star \star \star}(0.07)$ \\
\hline $\begin{array}{l}\text { Permanent price } \\
\text { elasticity }\end{array}$ & & & -1.14 & -1.43 \\
\hline $\ln Y_{i, t}$ & $0.51 \star \star \star(0.11)$ & $0.51 \star \star \star(0.01)$ & $0.08 \star \star \star(0.01)$ & $0.13 \star \star \star(0.02)$ \\
\hline $\ln Y_{i, t-1}$ & & & $0.15^{\star \star \star}(0.03)$ & $0.13 \star \star \star(0.01)$ \\
\hline $\ln Y_{i, t+1}$ & & & $0.39 \star \star \star(0.07)$ & $0.36^{\star \star \star}(0.02)$ \\
\hline $\begin{array}{l}\text { Permanent income } \\
\text { elasticity }\end{array}$ & & & 0.61 & 0.61 \\
\hline Other controls & Yes & Yes & Yes & Yes \\
\hline Year dummies & Yes & Yes & Yes & Yes \\
\hline$N$ in thousands & 366.5 & 366.5 & 306 & 252 \\
\hline
\end{tabular}

Source: Taxpayerpanel 2001-2006, author's own calculations

Notes: Standard errors in parentheses

$\star \star \star$ Significant at 0.01 level, $\star \star$ significant at 0.05 level, $\star$ significant at 0.1 level

Given the steepness of the log function at low levels of donations, I conduct a robustness check by adding $€ 5$ or $€ 10$ alternatively. This results in somewhat lower absolute coefficient estimates of price elasticity due to the shift towards a less steep part of a logarithmic curve (see Table 12.8).

\subsection{Excluding nonitemizers and border itemizers}

Finally, I present the results from a regression in which I exclude nonitemizers and border itemizers (see Table 12.9). On average, $30 \%$ of the tax units take the standard deduction, and less than $1 \%$ are classified as border itemizers. As some individuals switch between itemizing and not itemizing in subsequent years, I lose around $42 \%$ of my sample. The estimates of tax-price elasticity are somewhat lower and those of income elasticity somewhat higher than those in Table 12.5 .

\section{Conclusions}

This chapter analyzes the effectiveness of fiscal incentives for charitable giving in Germany. While there are numerous studies estimating tax-price elasticity of giving for the United States, we know little about European countries. Given this lack of knowledge as well as the different role of the government and different tradition of charitable giving, the widespread preferential treatment of donations in the income tax is striking.

This chapter provides new evidence from the German Taxpayer Panel 2001-2006. The availability of longitudinal data allows for the estimation of the permanent and transitory taxprice and income elasticity of donations while controlling for individual unobserved characteristics. The results suggest heterogeneous effects of the tax-price among different income groups. 
Table 12.8 Permanent and transitory effects. Assuming coefficients are uniform across income classes. Adding different constants to donations. IV approach to price and income. Dependent variable: $\ln D O N_{i, t}$

\begin{tabular}{|c|c|c|c|c|c|c|}
\hline & \multicolumn{2}{|l|}{+1} & \multicolumn{2}{|l|}{+5} & \multicolumn{2}{|l|}{+10} \\
\hline & $\begin{array}{l}\text { Perfect } \\
\text { foresight }\end{array}$ & $\begin{array}{l}\text { Predictable } \\
\text { tax change } \\
\text { instrument }\end{array}$ & $\begin{array}{l}\text { Perfect } \\
\text { foresight }\end{array}$ & $\begin{array}{l}\text { Predictable } \\
\text { tax change } \\
\text { instrument }\end{array}$ & $\begin{array}{l}\text { Perfect } \\
\text { foresight }\end{array}$ & $\begin{array}{l}\text { Predictable } \\
\text { tax change } \\
\text { instrument }\end{array}$ \\
\hline $\ln P R I C E_{i, t}$ & $\begin{array}{r}-0.03 \star \star \\
(0.01)\end{array}$ & $\begin{array}{r}0.05^{\star \star} \\
(0.02)\end{array}$ & $\begin{array}{l}0.00 \\
(0.01)\end{array}$ & $\begin{array}{r}0.07 \star \star \\
(0.01)\end{array}$ & $\begin{array}{r}0.01 \star \star \\
(0.01)\end{array}$ & $\begin{array}{r}0.07 \star \star \star \\
(0.01)\end{array}$ \\
\hline $\ln P R I C E_{i, t-1}$ & $\begin{array}{c}-0.33^{\star \star \star} \\
(0.01)\end{array}$ & $\begin{array}{c}-0.43 \star \star \star \\
(0.01)\end{array}$ & $\begin{array}{c}-0.31 \star \star \star \\
(0.01)\end{array}$ & $\begin{array}{c}-0.31 \star \star \star \\
(0.01)\end{array}$ & $\begin{array}{c}-0.19 \star \star \star \\
(0.01)\end{array}$ & $\begin{array}{c}-0.26 \star \star \star \\
(0.01)\end{array}$ \\
\hline $\ln P R I C E_{i, t+1}$ & $\begin{array}{r}0.02 \star \star \\
(0.01)\end{array}$ & $\begin{array}{l}0.01 \\
\quad(0.01)\end{array}$ & $\begin{array}{r}0.05^{\star \star} \\
(0.02)\end{array}$ & $\begin{array}{r}0.05^{\star \star} \\
(0.02)\end{array}$ & $\begin{array}{r}0.05 \star \star \\
(0.01)\end{array}$ & $\begin{array}{r}0.06 \star \star \\
(0.02)\end{array}$ \\
\hline $\begin{array}{l}\text { Permanent } \\
\text { price } \\
\text { elasticity }\end{array}$ & -0.33 & -0.37 & -0.17 & -0.19 & -0.12 & -0.12 \\
\hline $\ln Y_{i, t}$ & $\begin{array}{r}0.21 \star \star \star \\
(0.00)\end{array}$ & $\begin{array}{r}0.26 \star \star \star \\
(0.01)\end{array}$ & $\begin{array}{r}0.17 \star \star \star \\
(0.00)\end{array}$ & $\begin{array}{l}0.21 \star \star \star \\
(0.00)\end{array}$ & $\begin{array}{r}0.15^{\star \star \star} \\
(0.00)\end{array}$ & $\begin{array}{l}0.19 \star \star \star \\
(0.00)\end{array}$ \\
\hline $\ln Y_{i, t-1}$ & $\begin{array}{r}0.02 \star \star \star \\
(0.00)\end{array}$ & $\begin{array}{r}0.02 \star \star \\
(0.01)\end{array}$ & $\begin{array}{r}0.02^{\star \star \star} \\
(0.00)\end{array}$ & $\begin{array}{l}0.02^{\star \star} \\
(0.00)\end{array}$ & $\begin{array}{r}0.02^{\star \star \star} \\
(0.00)\end{array}$ & $\begin{array}{l}0.01 \star \star \star \\
(0.00)\end{array}$ \\
\hline $\ln Y_{i, t+1}$ & $\begin{array}{r}0.07 \star \star \star \\
(0.00)\end{array}$ & $\begin{array}{r}0.15^{\star \star \star} \\
(0.02)\end{array}$ & $\begin{array}{r}0.05^{\star \star \star \star} \\
(0.00)\end{array}$ & $\begin{array}{l}0.11 \star \star \star \\
(0.01)\end{array}$ & $\begin{array}{r}0.05^{\star \star \star \star} \\
(0.00)\end{array}$ & $\begin{array}{l}0.10^{\star \star \star} \\
(0.01)\end{array}$ \\
\hline $\begin{array}{c}\text { Permanent } \\
\text { income } \\
\text { elasticity }\end{array}$ & 0.31 & 0.43 & 0.24 & 0.33 & 0.21 & 0.30 \\
\hline $\begin{array}{l}\text { Other controls } \\
\times \text { income } \\
\text { class }\end{array}$ & Yes & Yes & Yes & Yes & Yes & Yes \\
\hline $\begin{array}{l}\text { Year effects } \times \\
\text { income class }\end{array}$ & Yes & Yes & Yes & Yes & Yes & Yes \\
\hline $\begin{array}{l}\text { Fixed } \\
\text { individual } \\
\text { effects }\end{array}$ & Yes & Yes & Yes & Yes & Yes & Yes \\
\hline$N$ in millions & 3.36 & 2.72 & 3.36 & 2.72 & 3.36 & 2.72 \\
\hline
\end{tabular}

Source: Taxpayerpanel 2001-2006, author's own calculations

Notes: Standard errors in parentheses

$\star \star \star$ Significant at 0.01 level, $\star \star$ significant at 0.05 level, $\star$ significant at 0.1 level

The estimates of permanent tax-price elasticity range between -0.2 for lower incomes and -1.6 for higher incomes. The average permanent price elasticity weighted with the amount of giving by different income groups is slightly below -1 , meaning that fiscal incentives for donations in Germany are effective. There is evidence that donors adjust their donations gradually after changes in the tax schedule and respond to future predictable changes in price. They respond mainly to changes in current and, to a smaller extent, in future income. The estimates for permanent income elasticity are around $0.2-0.3$, slightly varying among different income classes. Actual income and to some extent future income drive donations. The effects of past income are negligible. 


\section{Tax-price elasticity of donations}

Table 12.9 Permanent and transitory effects. Assuming coefficients are uniform across income classes. IV approach to price and income. Excluding nonitemizers and border itemizers. Assuming perfect foresight. Dependent variable: $\ln D O N_{i, t}$

\begin{tabular}{|c|c|}
\hline $\ln P R I C E_{i, t}$ & $0.06^{\star \star}(0.02)$ \\
\hline $\ln P R I C E_{i, t-1}$ & $-0.29 \star \star \star(0.02)$ \\
\hline $\ln P R I C E_{i, t+1}$ & $-0.02(0.02)$ \\
\hline Permanent price elasticity & -0.25 \\
\hline $\ln Y_{i, t}$ & $0.27 \star \star \star(0.01)$ \\
\hline $\ln Y_{i, t-1}$ & $0.02 \star \star \star(0.01)$ \\
\hline $\ln Y_{i, t+1}$ & $0.10 \star \star \star(0.00)$ \\
\hline Permanent income elasticity & 0.39 \\
\hline Other controls & Yes \\
\hline Year effects & Yes \\
\hline Fixed individual effects & Yes \\
\hline$N$ in millions & 1.97 \\
\hline
\end{tabular}

Source: Taxpayerpanel 2001-2006, author's own calculations

Notes: Standard errors in parentheses

$\star \star \star$ Significant at 0.01 level, $\star \star$ significant at 0.05 level, $\star$ significant at 0.1 level

\section{Notes}

1 The average marginal tax weighted by income in 2001 was around 32\% (own calculations). For more income tax statistics, see Buschle (2006).

2 See the literature section of this chapter.

3 For more information, see Welfare Expenditure Report (2001), http://www.oecd.org/dataoecd/56/37/31613113.xls (viewed on 8.2.2021).

4 For more information, see International Comparisons of Charitable Giving (2006), https://www. cafonline.org/docs/default-source/about-us-publications/international-comparisons-of-charitablegiving.pdf (viewed on 8.2.2021). The numbers for Germany exclude the church tax, which is between 8 and $9 \%$ (depending on the state) of the tax due.

5 For more information, see Andreoni and Payne (2013, p. 10).

6 For more information, see Deutscher Spendenmonitor (2011), www.tns-infratest.com/presse/presseinformation.asp?prID $=832$ (viewed on 8.2.2021).

7 For more information, see Sommerfeld (2009).

8 Most of the organizations offer the possibility of membership; examples include the WWF and Greenpeace. The members usually receive a regular magazine informing about the program achievements and the like.

9 See the literature section of this chapter.

10 The church tax is not included, because it is automatically deducted from the income of all members of the Catholic and Protestant church as well as of some Jewish and some free church congregations and amounts to between 8 and $9 \%$ (depending on the state) of the tax due. For a study on the interrelation of church tax and charitable giving in Germany, see Bittschi et al. (2015).

11 See, for example, Feldstein and Taylor (1976) or Feenberg (1988).

12 See Section 4.3 for the enumeration of control variables used in the estimation.

13 For example, McClelland and Brooks (2004) find that more education is significantly correlated with donations, and Brooks (2002) finds similar effects for wealth.

14 Individuals can be more or less altruistic, which may affect the choice of occupation and consequently the income.

15 Most observations in my sample will have finished their education and, if not, education years will change linearly, which does not pose a problem. Wealth changes will be captured to some extent by time effects. 
16 Those are the taxpayers who exceed their blanket allowance only due to their donation.

17 Indeed, in Germany, the blanket allowance for extraordinary expenses including donations is low (€36) as compared to the U.S. treatment.

18 The following programs offer partial solutions: Pantob implements Honoré (1992); LIMDEMP implements the fixed-effects Tobit model with up to 50,000 individual effects. However, Bradley et al. (2005) criticize applying such methods like Tobit or Heckman's two-stage method to address censoring in charitable donations. They observe that specification tests reject the assumptions about the form of the likelihood function in the selection equation, which is necessary for the consistency of these estimators. While they opt for semi- and nonparametric methods, they claim that their elasticities are similar to those obtained using panel data estimation methods.

19 Bakija and Heim (2011) include one more lag in their specification, but their panel is much longer. They estimate an equation equivalent to 3 . Their price coefficients enter as $\gamma_{1}\left({\ln P R I C E_{i t}}_{i t} \ln P R I C E_{i t-1}\right)+\gamma_{2} \ln P R I C E_{i t}+\gamma_{3}\left(\ln P R I C E_{i t+1}-\ln P R I C E_{i t}\right)$. Rearranging, this gives $\left(-\gamma_{1}\right) \ln P R I C E_{i t-1}+\left(\gamma_{1}+\gamma_{2}-\gamma_{3}\right) \ln P R I C E_{i t}+\gamma_{3} \ln P R I C E_{i t+1}$ such that $\delta_{1}=-\gamma_{1}, \delta_{2}=\gamma_{1}+\gamma_{2}-\gamma_{3}$, and $\delta_{3}=\gamma_{3}$. Then the persistent price effect is given by $\gamma_{2}\left(=-\gamma_{1}+\gamma_{1}+\gamma_{2}-\gamma_{3}+\gamma_{3}\right)$, the transitory effect by $\gamma_{1}+\gamma_{2}-\gamma_{3}$, and the effect of an anticipated increase in price next year by $\gamma_{3}$. They treat their income coefficients analogously.

20 For example, in the sample used by Bakija and Heim (2011), the average donation is $\$ 125,000$ (in 2007 dollars). However, the average after-tax income is greater than $\$ 1$ million.

21 For example, Paqué (1996) found the price elasticity to be between -1.8 and -1.4 and Borgloh (2008) between -2.08 and 0.84 .

22 See Priller and Schupp (2011).

23 Due to the computational constraint of the statistical office, this estimation was only possible with an $0.05 \%$ sample. Consequently, the number of observations is 10 times lower than in the other estimations.

\section{References}

Andreoni J. and Payne A. A. (2013) 'Charitable Giving', in Auerbach A. J. et al. (eds) Handbook of Public Economics. Amsterdam: Elsevier B.V., pp. 1-50. doi: 10.1016/B978-0-444-53759-1.00001-7.

Auer L. and Kalusche A. (2010) 'Steuerliche Spendenanreize: Ein Reformvorschlag, Jahrbuch für Wirtschaftswissenschaften', Review of Economics, 61(3), pp. 241-261.

Bakija Jon (2000) Distinguishing Transitory and Permanent Price Elasticities of Charitable Giving with Preannounced Changes in Tax Law. https://www.researchgate.net/publication/46468165_Distinguishing_Transitory_ and_Permanent_Price_Elasticities_of_Charitable_Giving_with_Pre-Announced_Changes_in_Tax_ Law.

Bakija J. and Heim B. T. (2011) 'How Does Charitable Giving Respond to Incentives and Income? New Estimates from Panel Data', National Tax Journal, 64(2), pp. 615-650. doi:10.3386/w14237.

Barrett K. S., McGuirk A. M. and Steinberg R. (1997) 'Further Evidence on the Dynamic Impact of Taxes on Charitable Giving', National Tax Journal, 50(2), pp. 321-334. doi:10.2307/41789261.

Bittschi Benjamin, Borgloh Sarah and Wigger Berthold U. (2015) 'Secularization, Tax Policy and Prosocial Behavior', Beiträge zur Jahrestagung des Vereins für Socialpolitik 2015: Ökonomische Entwicklung - Theorie und Politik- Session: Public Good Contributions. Kiel: ZBW - Deutsche Zentralbibliothek für Wirtschaftswissenschaften, Leibniz-Informationszentrum Wirtschaft.

Bönke T., Massarrat-Mashhadi N. and Sielaff C. (2013) 'Charitable Giving in the German Welfare State: Fiscal Incentives and Crowding Out', Public Choice, 154(1), pp. 39-58. doi:10.1007/s11127-011-9806-y.

Bönke T. and Werdt C. (2015) Charitable Giving and Its Persistent and Transitory Reactions to Changes in Tax Incentives: Evidence from the German Taxpayer Panel. https://ideas.repec.org/p/zbw/fubsbe/20152.html.

Borgloh Sarah (2008) What Drives Giving in Extensive Welfare States? The Case of Germany. ZEW Discussion Paper No. 8-123, Mannheim: ZEW.

Boskin M. J. and Feldstein M. (1977) 'Effects of the Charitable Deduction on Contributions by Low Income and Middle Income Households: Evidence From the National Survey of Philanthropy', The Review of Economics and Statistics, 59(3), pp. 351-354.

Bradley Ralph, Holden Steven and Robert McClelland (2005) 'A Robust Estimation of the Effects of Taxation on Charitable Contributions', Contemporary Economic Policy, 23(4), pp. 545-554. 


\section{Tax-price elasticity of donations}

Broman Amy J. (1989) 'Statutory Tax Rate Reform and Charitable Contributions: Evidence from a Recent Period of Reform', Journal of the American Taxation Association, 10, pp. 7-21.

Brooks Arthur C. (2002) 'Welfare Receipt and Private Charity', Public Budgeting and Finance, 22(3), pp. 101-114.

Buschle Nicole (2006) 'Spenden in Deutschland, Ergebnisse der Einkommensteuerstatistik 2001', Wirtschaft und Statistik, 2, pp. 151-159.

Clotfelter Charles T. (1980) 'Tax Incentives and Charitable Giving: Evidence from a Panel of Taxpayers', Journal of Public Economics, 13, pp. 319-340.

Fack Gabrielle and Landais Camille (2010) 'Are Tax Incentives for Charitable Giving Efficient? Evidence from France', American Economic Journal: Economic Policy, 2(2), pp. 117-141.

Feenberg Daniel (1988) 'Are Tax Price Models Really Identified: The Case of Charitable Giving', National Tax Journal, 40(4), pp. 629-633.

Feldstein Martin and Taylor Amy (1976) 'The Income Tax and Charitable Contributions', Econometrica, 44(6), pp. 1201-1222.

Honoré Bo (1992) 'Trimmed LAD and Least Squares Estimation of Truncated and Censored Regression Models with Fixed Effects', Econometrica, 60(3), pp. 533-565.

McClelland Robert and Brooks Arthur C. (2004) 'What Is the Real Relationship Between Income and Charitable Giving?', Public Finance Review, 32, pp. 483-497.

Paqué K. H. (1996) Philanthropie und Steuerpolitik - Eine ökonomische Analyse der Förderung privater Wohltätigkeit. Tübingen: Mohr Siebeck.

Priller Eckhard and Schupp Jürgen (2011) 'Soziale und ökonomische Merkmale von Geld- und Blutspendern in Deutschland', DIW Wochenbericht, 29, pp. 3-10.

Randolph W. C. (1995) 'Dynamic Income, Progressive Taxes, and the Timing of Charitable Contributions', Journal of Political Economy, 103(4), pp. 709-738. doi:10.1086/262000.

Reece W. and Zieschang K. (1985) 'Consistent Estimation of the Impact of Tax Deductibility on the Level of Charitable Contributions’, Econometrica, 53(2), pp. 271-294.

Sommerfeld Jana (2009) 'Bericht zum Forschungsauftrag fe 17/07, Evaluierung von Auswirkungen des Gesetzes zur weiteren St ärkung des bu ̈̈gerschaftlichen Engagements. Empirische Untersuchung der Entwicklungen im Regelungsbereich, insbesondere zum Spendenaufkommen', DZI.

Triest Robert K. (1998) 'Econometric Issues in Estimating the Behavioral Response to Taxation: A Nontechnical Introduction', National Tax Journal, 51(4), pp. 761-772. 